\title{
Precision Poverty Alleviation in Rural Tourism and Its Path Exploration
}

\author{
Shuhong Ma \\ School of Management, Bohai University, Jinzhou, 121013, China
}

529980721@qq.com

Keywords: rural tourism; precision poverty alleviation; theoretical basis; development mode; related subject; path exploration

\begin{abstract}
Accurate poverty alleviation is a poverty-stricken method that applies scientific and effective procedures to the implementation of precise identification, precise assistance and precise management of poverty alleviation targets in different poverty-stricken areas and different poverty-stricken households. Rural tourism is precisely helping the poor. In the poverty-stricken areas with certain tourism resources, location advantages and market foundation, the development of tourism will drive the economic development of the entire region, help the poor to get rid of poverty and win the battle for poverty alleviation. Guided by the theoretical basis of rural tourism precision poverty alleviation, this paper designs the development model of rural tourism projects, clarifies the relevant subjects of rural tourism precision poverty alleviation, analyzes the role of government in the precise poverty alleviation of rural tourism and proposes the precise poverty alleviation of rural tourism. Implementation path. The research results enrich the research theory of tourism poverty alleviation and provide guidance for rural tourism precision poverty alleviation practice.
\end{abstract}

\section{Introduction}

Poverty is a world problem that needs to be solved urgently along with the development of human society. Solving the problem of poverty reflects the needs of social common development and humanistic care. As the largest developing country in the world, China has a particularly prominent problem of regional poverty. However, due to the unclear poverty-stricken residents in the early poverty alleviation work, the lack of targeted poverty alleviation, and the inaccurate pointing of aid materials, the poverty alleviation work has encountered historical bottlenecks. As China's socialism enters a new era, the government attaches great importance to solving the poverty problem and reducing the gap between the rich and the poor. The poverty alleviation project has been vigorously carried out nationwide and has achieved remarkable results. The poverty alleviation method has been innovated, from "transfusion-type" poverty alleviation to "hematopoietic" poverty alleviation open new ideas for poverty alleviation.

Rural tourism is a product of the rapid pace of modern life and urbanization. With the economic and social development of China and the construction of beautiful countryside, rural tourism has developed rapidly. The government's strong support for rural tourism has injected a strong impetus into the development of rural tourism and created conditions for tourism to promote poverty alleviation. With the development of tourism poverty alleviation in some parts of China, the huge radiation belt has received wide attention from the government and scholars. The tourism precision poverty alleviation model is a promotion and breakthrough of the traditional tourism poverty alleviation model, alleviating various contradictions arising in the process of carrying out traditional tourism poverty alleviation work, but there have also been many new problems. Through the research of this topic, we will make suggestions for the development of rural tourism precision poverty alleviation, help solve a series of practical problems in the process of tourism poverty alleviation and promote the preferential poverty alleviation of rural tourism in the economic, social and ecological fields to maximize benefits, but also other forms. Provide a reference for precision poverty alleviation and development of rural tourism. 


\section{Theoretical Basis of Precision Poverty Alleviation in Rural Tourism}

The basic theory refers to the study of the general laws or main laws of the social economic movement and provides a guiding theoretical basis for the applied research. The research involves the following basic theories:

(1) Comparative advantage theory. Focusing on the optimal use of regional economic resources, the core idea is to organize local economic activities according to regional resource advantages. Poverty-stricken areas should choose development resources that meet local comparative advantages and encourage industries with comparative advantages to develop first. Although tourism has a quick effect on poverty alleviation, it is not suitable for all poor areas. Only when poverty-stricken areas have the relevant conditions for the development of tourism, it is possible to achieve the expected poverty alleviation effect by adopting the tourism precision poverty alleviation method.

(2) Stakeholder theory. Stakeholders have an impact on the achievement of organizational goals and are also influenced by the process by which the organization achieves its goals. To achieve long-term stable development, it is necessary to meet the requirements of key important stakeholders. Due to the comprehensive nature of rural tourism and the high degree of relevance, there are many stakeholders involved, and the interrelationship among various stakeholders is complex and changeable. Therefore, to carry out rural tourism development planning in a region, the decision-making must fully meet the requirements of various stakeholders.

(3) Theory of sustainable development. To meet the needs of the present, and not to harm the ability of future generations to meet their needs, the basic principles of fairness, continuity and commonality, the ultimate goals is to achieve common, coordinated, fair, efficient and multidimensional development. The concept of sustainable development in tourism precision poverty alleviation emphasizes the protection and sustainable use of tourism resources and environment. While improving the poverty situation, it also ensures the ability of tourism to help the poor and the target population to achieve sustainable development.

\section{Development Mode of Rural Tourism Project}

There are many development models for rural tourism projects, and the following are commonly used:

(1) The joint mode of farmers and farmers. This is the business model in the early stages of rural tourism. In rural areas far from the market, farmers generally have certain concerns about the involvement of enterprises in rural tourism development. They are reluctant to give limited funds or land to the company, and they are more convinced of "model households". The "model households" first succeeded. Under their leadership, the farmers joined the ranks of tourist reception and learned the experience and technology from them. After a short break, they formed a rural tourism development model in which farmers and farmers combined.

(2) The cooperation mode between the company and the farmers. Incorporate farmers' participation in the operation and management of rural tourism and make full use of the idle assets and surplus labor of farmers to enrich tourism activities. Through the introduction of tourism companies, the tourism reception service will be standardized to avoid damage to tourists' interests due to bad competition. The cooperation between the company and the farmers is based on the economic foundation and is greatly affected by the strength of the company. In the process of internal management, how to carry out the diversion and distribution of tourists becomes the key to the smooth implementation.

(3) Company model. The characteristics are that the development is fast, the starting point is high, and the development has scale. If the ideas are correct and the management is scientific, it is easy to quickly embark on an orderly development path. The source of rural tourism and wealth is public resources and common resources of farmers, but the biggest beneficiary is tourism companies. As a participant in rural tourism, enthusiasm cannot be ignored. This model is more suitable for the initial stage of rural tourism. As farmers' attention increases, it is difficult to adapt to 
future development trends.

(4) Shareholding system model. Develop tourism resources in the form of cooperation and obtain corresponding income according to their respective shares. According to the property rights of tourism resources, it is defined as four property rights entities: the state, the rural collective, the villager group and the individual farmers. Adopting the method of cooperation between the state, the collective and the individual farmers, the tourism resources, special technologies and labor are converted into equity, and the income is combined with the dividends of the shares and the labor dividends. Adopting this model is conducive to achieving a deeper transformation of farmers' participation.

(5) Individual farm mode. With the development of large-scale agricultural self-employed households, they will appear in the form of "travel-based self-employed households". Through the transformation of their own farming, animal husbandry and fruit farms and the construction of tourism projects, it will become a complete tourist attraction and can complete tourism reception and service work. Through the development of individual farms, the nearby idle labor force is absorbed and joined into the service industry through handicrafts, performances, services and production to form a development model with a point-to-face approach.

\section{Related Subject of Precision Poverty Alleviation in Rural Tourism}

The relevant subjects of rural tourism precision poverty alleviation include government, tourism enterprises, poor people and tourists. The brief description is as follows:

(1) Government. The government manages all aspects of poverty alleviation, including policy formulation, system design, capital investment, tourism training and tourism resource protection. Specifically, on the one hand, through the formulation of rural tourism precision poverty alleviation policies and design poverty alleviation assistance system, help poor areas to create a good rural tourism development environment, and guide tourism poverty alleviation development; on the other hand, set up special funds for tourism development, through increased funds We will continue to improve infrastructure such as road traffic, communications and hydropower, provide tourism development funds and training opportunities for the poor, improve individual skills, and ensure the development of tourism poverty alleviation.

(2) Tourism enterprises. Tourism enterprises provide technology and funds, carry out tourism business activities, and promote economic development in poverty-stricken areas. The main functions include four aspects: first, investing in tourism in poverty-stricken areas, building infrastructure such as transportation and water and electricity, and improving the living environment of villagers; second, carrying out tourism business activities, providing employment opportunities, and improving the quality and skills of local residents; Third, the planting industry and aquaculture industry will be integrated into the tourism industry chain, establish long-term business relationships with local residents, and broaden the sales channels of agricultural products. Fourth, through the development of tourism, increase the amount of tourism enterprises to pay, and promote local fiscal revenue growth.

(3) Poor population. As an implementation target of precision poverty alleviation, the poor population is an important subject of accurate assistance for poverty alleviation in rural tourism. The willingness to participate, the ability to participate, the way of participation and the level of participation of the poor directly determine the effectiveness of rural tourism poverty alleviation. Therefore, the poor are not only the beneficiaries of rural tourism poverty alleviation, but also the inheritors of local traditional culture. On the one hand, we will change the ideological concept of "waiting, relying on, and wanting" to form a self-development awareness of the poor. On the other hand, through the development of skills training, improve the quality of the poor, and participate in rural tourism activities in the form of employment and entrepreneurship to get paid.

(4) Tourists. Tourists are the main consumers in the tourism market. The degree of satisfaction of tourists with tourism products and tourism services directly determines the degree of tourism development. Changes in the demand of tourists affect the direction of tourism development. By purchasing tourism products and services in poor areas, tourists have broadened the income 
channels of the poor and increased the income of the poor. The positive evaluation and feedback of tourists on the tourism experience will help to adjust the tourism projects in poverty-stricken areas. In addition, the word-of-mouth publicity of tourists has become an effective way of rural tourism marketing in poverty-stricken areas, which can promote the image of rural tourism in poverty-stricken areas.

\section{Role of Government in Precision Poverty Alleviation in Rural Tourism}

The role of the government in the precise poverty alleviation of rural tourism is mainly reflected in four aspects:

(1) Increase financial support. The government should increase financial support to solve the problem of funds for rural tourism to help the poor. To this end, the government should formulate fiscal policies, set up special funds for rural tourism to ensure poverty alleviation, and ensure the use of rural tourism for precise poverty alleviation, and provide financial support for rural tourism to ensure poverty alleviation. At the same time, we will broaden the sources of accurate poverty alleviation funds for rural tourism, introduce tax incentives, encourage enterprises to participate in rural tourism and ensure poverty alleviation, and meet the funding needs of rural tourism for poverty alleviation.

(2) Clearly dominant position. The government should clarify its dominant position and strengthen its guidance on the precise poverty alleviation of rural tourism. To this end, on the basis of the rural tourism precision poverty alleviation policy, the government should introduce relevant supporting measures, improve the supporting mechanisms, and promote the smooth implementation of rural tourism precision poverty alleviation. Moreover, the government should strengthen specific guidance on the specific work of rural tourism to ensure poverty alleviation, clarify the goal of poverty alleviation in rural tourism and poverty alleviation methods, and ensure that rural tourism precision poverty alleviation work is implemented.

(3) Improve interest appeals. In response to the irrational appeal of interests, the government should actively improve the interests of rural tourism to ensure poverty. Firstly, to clarify the role of rural tourism in ensuring poverty and the development of poverty in China, and to grasp the purpose of precision tourism for rural tourism. At the same time, the rural tourism precision poverty alleviation and economic development will be placed in the same position, and the emphasis on rural tourism precision poverty alleviation will be strengthened. In addition, from the perspective of farmers, the demand for accurate tourism poverty alleviation in rural tourism is consistent with the interests of farmers.

(4) Strengthen organizational management. The government should give full play to the organization and management of accurate tourism poverty alleviation in rural tourism, actively improve the management department, clarify the responsibilities and management content of the management department, and ensure the smooth implementation of rural tourism precision poverty alleviation management. Moreover, the government should actively formulate the objectives and management evaluation indicators for rural tourism precision poverty alleviation, strengthen the application of information technology and network technology in rural tourism precision poverty alleviation management, and improve the government's rural tourism precision poverty alleviation management efficiency.

\section{Implementation Path of Precision Poverty Alleviation in Rural Tourism}

Rural tourism precision poverty alleviation has achieved some achievements in the implementation process, but there are also many problems, and it is necessary to formulate practical solutions. The development path proposed in this paper is as follows:

(1) Strengthening the investigation and study of the poor population and tourism resources. In order to improve the accuracy and effectiveness of rural tourism poverty alleviation, it needs to be examined and identified in the following aspects: First, investigate the rural tourism resources, analyze its development value, and popularize the importance of rural tourism for poverty 
alleviation and the party. The political program promotes the implementation and implementation of poverty alleviation work; the second is to conduct a comprehensive survey of the poor population, produce a complete poverty population statistics table and a list of poor villages, and provide support for rural tourism precision poverty alleviation decision-making; third, establish a sound The poverty population identification mechanism screens the population and tourism resources that really need poverty alleviation support to ensure the targeted and effective poverty alleviation work of rural tourism. Fourth, increase the dynamic management of poor households to ensure the true and accurate information. Sexuality play the substantive role of rural tourism and poverty alleviation.

(2) Improve the quality and skills of the poor to participate in tourism for poverty alleviation. Tourism is a service-oriented industry, and the quality of practitioners is related to the success or failure of tourism. First, help people in poverty-stricken areas to establish a correct concept of poverty alleviation, so that people can accept rural tourism from the heart and actively participate in it; second, strengthen the educational investment in the poor areas from the government level, through the form of short-term training courses, Improve the cultural quality of women and the elderly in poverty-stricken areas, popularize Putonghua, and master basic catering service skills to ensure the quality of rural tourism services; Third, popularize the national tourism precision poverty alleviation policy, establish a representative figure of participating in tourism precision poverty alleviation, increase people Confidence and determination to get rid of poverty and get rich, and provide practical technical training for the poor population in planting, breeding and processing agricultural products.

(3) Clarify the role of the relevant subject. The relevant subjects of rural tourism precision poverty alleviation include the government, tourism enterprises, the poor and tourists. The government occupies a special position in the tourism industry and has strong authority. It is the maker of the rural tourism poverty alleviation policy. It plays a leading role in the early stage of tourism poverty alleviation. With the effective development of rural tourism poverty alleviation work, it gradually shifts to the direction of the instructor. The poor are the beneficiaries of tourism poverty alleviation and play an important role in the process of tourism poverty alleviation. Tourism enterprises are the main investors in the construction of rural tourism precision poverty alleviation projects and carry out tourism business activities according to law. Tourists play the role of public opinion orientation and supervision and evaluation in tourism poverty alleviation work and play the role of supervisor and promoter. Defining the role orientation of each subject is conducive to promoting the various departments to perform their duties and ensuring the orderly progress of rural tourism precision poverty alleviation.

(4) Develop distinctive tourism projects. The characteristic is the soul. Without features, it is difficult to survive and develop. The cultural tourism resources with rural characteristics are packaged into different types of tourism route products, which are promoted to the market through the modern "tourism +" marketing model and promote the development of global tourism to the precise poverty alleviation region. Make full use of its own characteristics and advantages, tap the characteristics and highlights of rural tourism resources; use the resources of civilized ecological villages and tourist-style towns, and focus on the construction of a number of rural tourism demonstration projects such as ancient villages, ethnic villages and ecological tourism; Different customer groups will launch creative products with local characteristics, rich cultural connotations and strong ornamentals; appropriately carry out rural leisure tourism activities with strong local characteristics and strong participation, and promote the development of tourism industry with the development of characteristic rural tourism products.

(5) Integrate rural tourism resources and promote industrial integration and development. Under the realistic background of scattered tourism resources and low visibility in tourism poverty alleviation areas, joint development and coordinated development with surrounding scenic spots can be carried out. First, to create an experiential rural sightseeing tour, allowing visitors to experience leisure during picking and excursions, and to increase the time spent by tourists in the scenic spot; second, to improve agricultural tourism, the agricultural sightseeing park is equipped with 
corresponding tourism facilities, and the development of agricultural knowledge popularization projects, Let tourists experience the fun of picking while understanding the production process and related knowledge of agricultural products. Third, develop education and sightseeing, and make agricultural tourism parks into outdoor classrooms, so that students can understand nature, learn agricultural knowledge and rural traditions in leisure and entertainment. Culture; Fourth, the development of the citizen garden, providing rental land services, allowing urban residents to enjoy farming and experience the pastoral life.

\section{References}

[1] Y. Zhang, H. L. Liu, "Research on the Precision Poverty Alleviation Strategy of Rural Tourism," Tourism Overview, vol. 8, no. 8, pp. 162-163, 2018.

[2] J. Zhang, "The Realistic Dilemma and Resolution Path of Rural Tourism Accurate Poverty Alleviation," Economic Research Guide, vol. 14, no. 23, pp. 34-36, 2018.

[3] Y. L. Jin, H. Zhang, "Research on the Path of Precision Poverty Alleviation for Rural Touris," Journal of Chifeng University(Philosophy and Social Science Chinese Edition), vol. 39, no. 7, pp. 65-67, 2018.

[4] Y. Li, "Research on the Precision Poverty Alleviation Strategy of Rural Tourism," Tourism Overview, vol. 8, no. 8, pp. 142-144, 2018.

[5] Y. L. Zhou, "Study on the Operation System and Promotion Strategy of Rural Tourism Precision Poverty Alleviation," Rural practical technology, vol. 21, no. 9, pp. 43-47, 2018.

[6] C. H. Zhang, "Innovative Exploration of the Mechanism of Tourism Precision Poverty Alleviation," Agricultural Economy, vol. 37, no. 9, pp. 58-59, 2017.

[7] R. Lu, "Analysis on the Precision Poverty Alleviation Mechanism of Rural Tourism," Marketing Management Review, vol. 14, no. 8, pp. 126-127, 2018. 